\title{
Uncanny objects and the fear of the familiar: Hiding from Akan witches in New York
}

City

This article examines the cosmology and secret practices of West African traditional priests in New York City in preventing the spread of witchcraft, an evil invisible spirit transmitted between female members of the Akan matrilineage. Explored is an uncanny dynamic as everyday habitus becomes increasingly strange in the world of a young Ghanaian woman in the Bronx, who has become petrified of insinuations of witchcraft from close family members. In trying to hide the young woman from infection by her fellow witches, Akan priests attempt to 'capture' her habits and everyday routines, calling upon the iconic magic of New York City in order to 'misplace' familiarity within the anonymity of Manhattan. In this process, the transmission of the witch's spirit to the intended victim is disturbed as the victim's life and things are moved. Nowhere to be found, the witch shifts her attention to other victims.

\section{Keywords}

Akan witchcraft, uncanny, New York, objects

\section{Introduction: Akan witchcraft and the uncanny object}

Amma, a young Ghanaian woman, aged twenty-one, lived in the West Bronx, New York City, the poorest congressional district in the United States (ICPH, 2014). She was part of a highly visible diaspora of West Africans who have migrated to the United States since the early 1980s and especially over the last fifteen years. Unconcerned about her long-term employment possibilities and future in New York, she had, like many young Ghanaian migrants, a high-school diploma and gained work at various times as a receptionist and also as a store worker. Amma, however, was petrified about becoming a witch and had come for help, under great secrecy, to 'a juju man' or Akan priest (okomfo) possessed by a shrine god (obosom) who trace their origins, like the Akan, Ghana's largest ethnic group, to the Central and Western Regions of Ghana (McLeod, 1981). She agonised that she might be accused of witchcraft at any time, a taboo subject among many Ghanaians and a hidden threat.

Witchcraft remains an unspoken fear often among even those Ghanaians who are quick to dismiss it as a ‘superstition’ or 'primitive belief'. Often (mis)diagnosed by medical professionals as a delusion and afflicting manic individuals suffering from depression, 
schizophrenia and psychosis (Field, 1960; Simpson, 2009; Palmer, 2013), she was increasingly agitated about witchcraft in relation to things which had previously gone unnoticed. One of the first statements she uttered in my presence was: "things do not seem the way they turned out to be”. She said that she could sniff evil in her home and about her clothes, as liquorice, a smell commonly associated with Akan witchcraft, and tried to warn it away by praying regularly and keeping herself busy. She felt scared, she told me, in a life she no longer recognised, living with her younger cousin while her older siblings and friends went about their own lives in the United States and Ghana. Her home appeared foreign to her and she no longer even liked her favourite potato chips which now tasted bitter (see also Parish 2011a). She felt that her makeup, which she carried everywhere, had been tampered with - her mascara had become clumped and the tip of her lipstick forced out of shape. Amma increasingly worried because in her life she said "nothing good changes much”. Meanwhile, she rarely left her home or travelled outside of the Bronx or to different areas of the city.

Appadurai (2006) analyses how the mysterious workings of global capitalism are also matched by new forms of migration that create unprecedented tensions and conflicts between identities of origin, residence and aspirations (2006:37). Amma's anxieties about the presence of evil draw attention to the cosmic (dis)ordering of witchcraft. West African witchcraft discourses usually thrive under conditions of instability and change, (Englund and Leach, 2000; Bonhomme, 2012). The Akan describe how witchcraft (obayi) is a dirty and unclean malevolent spirit that derives its increasing power from a mixture of human hair, fingernails, teeth and blood of the victims of the witch (Adinkrah, 2015). The witch (obayifo) hides these substances, along with her witchcraft power, in a container or pot (bayi kuku) usually deeply buried in the forest (Adinkrah, 2015). Using obayi, the witch leaves her body at night to cause a variety of trouble and misfortune - cocaine addiction, debt, mortgage foreclosure, car accidents and marital breakdown. In Ghana, within the kinship group, witchcraft works like an owned object (Crentsil, 2005). Since by virtue of the blood (and the womb) a person belongs to the matriline, lineage ideas determine the individual's place in the matrikin (Crentsil 2005; Parish 2015). This also gives the witch, commonly believed to be an envious and greedy woman in the kin group, the right over the individual (see Crentsil, 2005) and, according to witches, to "kill” him or her, or cause conflict and disaster as and when they want (Rattray, 1927; Debrunner, 1959; Douglas, 1970). 
Witchcraft remains popular as an explanation for adversity because it draws attention to the ways in which 'disruptive' events and conflicts acquire greater significance under different sets of relational conditions (Strathern and Stewart, 2004). While 'bewitching' is a constant threat and involves feelings by the witch of resentment towards her victims, there is also another type of more insidious anxiety - the sense that makes shrine clients feel apprehensive out of all proportion to their normal lives, where things just seem to be getting slowly worse because a 'witch is at their heels'. There is the belief that the witch is nearby and that the witch is trying to transfer her obayi spirit on. The transmission of witchcraft power between close kin is often believed to be an act of love, if not on the part of her victims, at least by the witch who sees her witchcraft (obayi) as a valuable substance (Adinkrah, 2015). Witchcraft may be spread in several ways. For example, it may be inherited through the abusua through intrauterine or congenital transfer. Obayi, has the ability to depart and return to a body and is transferable from mother or grandmother to daughter, sometimes even through spitting or breathing the witchcraft spirit into the mouth of a daughter (Adinkrah, 2015:112). More commonly, during the transfer of evil, obayi may be passed on through food, often red-palm oil or palm-fruit soup which is swallowed, or trinkets and jewellery such as necklaces and earrings, often received from elderly relatives, which are picked up, or, lastly, even via money (Adinkrah, 2015:111). Yet such is the social stigma of evil that to be accused of witchcraft is to risk social ostracism, punishment or sometimes even death at various times in Ghana (Goody, 1970; Palmer, 2013)

The emotive relation between a person susceptible to the transmission of obayi and their efforts to stop witchcraft accusation allows Akan priests in New York to hack into the infrastructure of materials and their sensory qualities (see also Larkin, 2008). This enables priests to distort the materiality of ordinary, even banal objects, 'through a thick cosmology' (da Col, 2012:192). As things become infected by obayi, ubiquitous objects - banknotes, perfume, hair brushes, keys - produce an increasing sense of unease as unconscious order and habitus become unusually strange. From brushing one's hair, to how one smells after showering or the satisfaction from drinking a coffee, as witchcraft spreads from its original source, its victims no longer feel at ease and comfortable, normal intuitions, hunches and unformulated ideas no longer occur automatically. In New York, Akan priests attempt to defer the contamination of their clients' lives with witchcraft, before it is too late, by moving 
personal routines and habits [from] their usual place as priests activate, in a series of social relationships, materials and invisible spirits (Crentsil, 2005; Ishii, 2012).

How can such familiar exchanges and habits become the gradual source of a frustration and emptiness that only an Akan god can deal with? The religious practices of juju men draw upon an Akan cosmological framework in order to demonstrate how a sense of comfort, habit and familiarity is no longer related to the opposition of the strange, but a blurring of boundaries between what is threatening and what is not, and what is close and what is distant (Masschelein, 2011:147). In doing this, Akan occult discourses draw upon a long history of ideas about spirits and witchcraft accusation among the Ghanaian kinship network (DruckerBrown, 1975; Meyer, 1998; Adinkrah, 2015). Yet, the propensity, argues Geschiere (2013a), within kinship relationships, of the recognised and accustomed to turn on its victims and provoke a sense of conflict has not stopped proximity and closeness from being viewed as something secure and stable and as being about trust and solidarity (Giddens, 1992). Home is a source of safety, a sort of secure space made up of ideas and realisations (Lupton, 2013). Yet 'homeliness' also has the power to turn so that what was once known becomes a source of the unexpected and disturbance (Chapman and Hockey, 1999). Elsewhere, I have described how young West African women, newly arrived in Europe, feel themselves to be an economic burden upon relatives, lonely, trapped and 'bewitched' within the 'home' and lacking in moral support (Parish, 2011a). West African witchcraft draws attention within the Ghanaian family of the dangers of intimacy which implies a specific outlook on domesticity and life behind closed doors.

Examining sociality within the West African diaspora, witchcraft progressively operates at a distance as intimate relations assume an increasing scale (see Geschiere, 2013a). While contemporary urban life increasingly thrives on rumour, speculation and innuendo about ‘inside enemies’ and the opaque motives of ‘outsiders’ (see Bonhomme, 2012; Geschiere, 2013b), and the 'distant' world may seem to embrace alienation and uncertainty, the stranger simultaneously also illustrates the unity of nearness and remoteness as he who is far is actually near (Simmel, 1950). In other words, witchcraft not only relates to the breakdown of intimate social relationships and personal alienation but, also, to large-scale meta-narratives of conflict as migrants seek to construct their own moral values and critiques of, for example, wealth, accumulation and materialism (Moore and Sanders, 2001; Englund, 2007; Trovalla, 
2012). West African witchcraft, in other words, captures awkward scales (Bonhomme, 2012), entailing different degrees of dispute among transnational migrants that are essential to understanding postcolonial notions of material transparency and the neutrality of objects.

Geschiere (2013a) looks to Freud [1919] (1983) to point out the relationship between familiarity and the strange through the concept of the uncanny in order to illuminate the ambiguity of close relationships and the presence of alien spirits (Geschiere, 2013a:68). The uncanny captures this tension in that it is about the relationship between the intimate and the unknown (Vidle, 1992). Though the uncanny is not clearly definable because it relies on a personal experience, Freud outlines circumstances that would be considered uncanny including unintended repetition and the double or Doppelgänger. Here it is important to understand the uncanny in the sense used by Heidegger as the incongruous in the familiar (Masschelein, 2011:22). It is a mixture of both the inexplicable and the known that cannot be resolved (Royal, 2003). The uncanny, understood as the emergence of a set of tangible but also elusive effects, can therefore be used to explore the conditions under which the unexpected comes about (Zizek, 2013).

Among those persons, like Amma, who could not dispel the doubt that a witch was trying to recruit her to a coven, the event captured by the uncanny is not about a sudden, disastrous occurrence that is immediately felt, such as an illness, accident or tragic happening, the inexplicable and out-of-the-ordinary misfortune. In Amma’s life, no great incident has occurred that may be attributable to witchcraft forces. Rather, in her case, the transference of witchcraft is about the articulation of recurrent forces and an oddness that takes time to appear as witchcraft takes hold of its victim, hidden amongst everyday belongings or even food, as the spiritual occult and the material realm intersect (Hanare, Holbroad and Pedersen, 2006). This marks an event that, at least for some clients, is a turning point for those involved, marking a strange ordinariness or an awkward relationship, especially with other female relatives in the matrilineage. It is the point, with hindsight, after which nothing is the same and which pulls the client back to fearfully examine the ordinary over and over again. The priest does not seek to master what I call here the uncanny, but recognises that there has to be attachment to the familiar in order to think about the extraordinary (Royle, 2003). So, among Akan priests, this vision is accomplished via everyday material objects belonging to 
clients, which are mislaid by the okomfo so that the confidence of finding an object in a certain place is disturbed.

In this complex world of strangeness and familiarity, witchcraft discourses flow far beyond an 'occult economy' (Comaroff and Comaroff, 1999) and into the anonymous city as priests make their own particular realities and deposit the contingency and unpredictability of their own sacred practices across the New York landscape (Parish, 2015). 'Esoteric registers are shifted to material registers and back again as spiritual presences pour into material worlds and objects' (Handleman, 2008:182). One of the most interesting things about this movement is that it gives access to an unfolding history, a glimpse of the cosmic model-in-the-making, as the magic of a New York landscape - especially Manhattan, which many clients of Akan priests have little knowledge of - is called upon to help cleanse the client of witchcraft in his or her personal life. Benjamin has highlighted how the street corner and street names become immersed in historical and metaphysical worship, allusions and connections: Broadway, $5^{\text {th }}$ Avenue, Central Park, Times Square, Bleecker Street, and Soho. New York becomes the 'prism of the possible' in relation to persons, images and ideas (1996:54). Among priests this is to highlight not only a New York lifestyle and etiquette of behaviour, but especially a Manhattan way of being: the protocol of sitting in a crowded subway car; of hailing a cab; of jaywalking; of living on the Upper West Side in contrast to the Lower East Side; or of dining late at night in Greenwich Village as opposed to Alphabet City. Like Manhattan itself, the sacred imagination is allowed, in this process, to stretch far beyond local confines as the real and the imaginary all impact on one another (Crapanzano, 2004). As Harvey and Knox (2014) write, if, in an attempt to reorganize 'figured worlds', human collective relations are constituted 'through and substantiated in the particular arrangement and possibilities of material things, then it makes sense to purposefully disrupt the order of things in order to potentially disturb the structure and organization of social life' (2014:21). Employed at shrines, the 'everyday' is misplaced and the effects of witchcraft discarded as 'the signifier acts as if it were real' (Taussig, 1993:3). The different world created by the Akan priest becomes more powerful than the original and 'real' world and the client is saved as the witch, unable to clearly locate the subject of her attention, finds another human agent to receive her witchcraft spirit. 


\section{Akan spirit priests: spirituality and materiality}

I met Amma when she visited an Akan okomfo in New York on several occasions over a period of a few months. Amma had heard about the "juju man” a year before through her sister who lived in London. In Forest Gate, East London, her sister had visited a "fetish priest” who sold powerful fertility treatments. Her sister had become pregnant soon after but felt obliged to keep making online financial payments to the priest, who she felt had helped her after years of miscarriages. He had sent Amma's sister the name of a fetish priest, Kwabena, in New York in case Amma needed similar help as witchcraft, he said, stalked the family around the world. A widespread sense of foreboding exists in that even the acknowledgment of the existence of 'traditional' spirit shrines may, it is feared, tempt grave misfortune or some other inexplicable terrible event befalling an individual. Those who dismiss 'fetish priests' often still fear them and believe their 'juju' powers to be destructive and derive from satanic forces.

Although I was unable to verify the location or even the identity of the particular fetish priest visited in London, in New York many different spirits and deities of numerous substance and religious backgrounds can be found. Having originally conducted fieldwork on witchcraft and shrines in the Brong-Ahafo Region of Ghana in the early 1990s, over the next ten years I traced a few Akan shrines to Europe within the growing African diaspora. Through these links and Ghanaian contacts in West Africa and the United States, I was eventually able, over a period of six or so years, to set up fieldwork between 2005-2010 in New York among a very small number of Akan priests (Parish, 2015). Many priests are immigrants who have arrived in the United States in the twenty-first century as undocumented migrants from Ghana and have since returned to Ghana (Krauss and Huewelmeier, 2010). They are employed in a variety of business activities, which are not always on the 'right' side of the law, especially if they have few clients and need to supplement their income. Their spirit shrines are very informal, but deeply secret places, their activities clandestine and found hidden in different boroughs including Brooklyn, Queens and the Bronx. These informal shrines appear and just as suddenly close, hidden in apartments and even carried in backpacks when the priest has powerful talismans to sell (Parish, 2011b). A few may, at their peak, receive several visitors a month, and many still less, being regarded as 'con' shrines by rival priests amid a wealth of accusation and counter-accusation about their origins, alleged 
criminal activities and swindling of clients. 'Juju men' deal with a variety of disasters and often financial misfortune. By retelling the misfortune, the witch, as one priest said, "come into the world”. It appears to guide the shrine god to the witch who is spied as a fireball in the night sky feeding with her pack. Spiritually attacked and hit by the god, she is 'forced' to come to the shrine in order to confess her sins and pay a large fee to the priest.

Amma came, with some trepidation, to visit Kwabena in a lock-up in Queens which belonged to Kwabena’s sometime employers. Here, Kwabena introduced her to his shrine god, an invisible spirit hidden in a soda can kept by him in the back of the building. Kwabena had migrated to New York in 2002 to live with his cousin. He worked as a repo man, running alongside this motor scams involving, among other things, the selling of fake driving licences. In early 2007, Kwabena dreamt that his god had called out at night to step away from the debt-collecting business, although he still did this part-time because religious business could be very slow. Kwabena's god (obosom) was believed by him to be a most powerful Akan spirit (sunsum) inhabiting a nondescript coke can wedged in rocks in the Atlantic waters lapping Battery Park. Kwabena had heard a voice shouting for him and, following the god's instructions, found the spirit of the god (obosom) in the soda can disguised as a very small pebble. As in Ghana, the dominant feature of Kwabena's shrine is possession (Goody, 1957; Field, 1960). Possession involves a set of exchanges that signify the presence of the god in order to hear the details of a client's case. In New York, during possession, the shrine priest carries the spirit of the god (obosom) held over his head; at one shrine, it was in an old milk carton on which he had stuck the picture and description of a missing person. The spirit (sunsum) of the missing person is believed to assist the god in his day-to-day living arrangements - buying the god whatever he desires, helping him dress, feeding him and keeping guard over magical talismans (asuman).

Amma, a regular Pentecostal church attender, felt "shame” visiting Kwabena and hoped that other family members would not discover her "confidential” visit. She came to the shrine, despite feeling that Kwabena was a "juju man” and an "evil” person, because she felt that she was helping her sister; to not come might be to tempt a witch into hurting her young niece or, worse, the fetish priest in London might see this as a slight and curse her sister's family and make Lola herself infertile or unable to find a future husband. Her eventual cautious visit was propelled by, what she felt, was an unspoken threat made by the fetish priest in London. But 
more than this, her anxiety about the future made her rethink a single unremarkable incident that now bothered her. Amma remembered how her aunt, a flamboyant woman, a personality trait commonly associated with Akan witchcraft, had borrowed a CD from her entitled 'Whitney', recorded by the female artist Whitney Houston. This occurred in the days leading up to Christmas, the climax of witchcraft activity as witches prepare to feast (Adinkrah, 2015). Her mother had heard the music on a radio station when she immigrated to New York in 2003, with Amma, to join her husband, before returning to Ghana a few years later. Amma reminisced how the CD had become one of her mother's favourite pieces of music and stood out among the gospel and highlife music she loved. 'Didn’t We Almost Have It All' and 'I Wanna Dance with Somebody’ remained two of her mother's most played songs - two pieces she played every Sunday and which she loved to sing along to and watch her children dance to in her small apartment. She had lent the CD to her aunt and expected her to enjoy this particular recording and return it when finished. She hadn't and events had taken a turn for the worse since her sister's visit to the fetish priest in London, but in a way that Amma could not quite put her finger on. She worried that her life had become stuck in a continuous bad moment in which she obsessed about the missing recording. She despaired that, like a fly caught in a spider's web, a witch had caught her life in the so-called 'witches' rope', used to tie up victims, and this had become entangled in her motionless days in her home, in her chores, in her hair, even in her bed. Increasingly, she could not leave her room as if she were pinned to the floor and she repetitively fixated on certain objects.

She began to feel anxious because the CD cover, she thought, pictured the figure of Satan with her aunt. Her favourite photographs of her mother, now living in Ghana, no longer felt the same to her. She could no longer remember the happy events they recalled such as her sister's baby being born and, instead, her everyday moments were disappearing, her habits caught in a downward spiral of lethargy and compulsive routines. She constantly repeated how "I am not in a good situation”. She told me in Kwabena’s presence how "Nothing gets ever finished.... This makes for ... serious financial burden...I look and look hard for a sign to make... better.... I am not me ...no longer”

Amma's scared feeling of watching over her own life stemmed from a strange power she reasoned could only be witchcraft. She had to be cut loose, she said, as the threat of witchcraft was nearby. She felt her aunt had trapped her and was herself a witch who was trying to drive her mad and was slowly contaminating her life, stopping then prodding her 
with an evil stick. She dreamt one night that she was flying with her aunt, sitting on top of a red fireball that blazed across the sky in her home town in Ghana, a common sign of witchcraft. Amma told Kwabena how she sometimes forgot about the unreturned CD only to wake up in the middle of the night wondering where it was. How could she have lost her mother's favourite music? What a terrible daughter she was to have forgotten about it. And then she would remember how it hadn't been returned and her long gestating resentment would begin all over again. Suffice to say that this grew until another copy of the recording was bought by Amma to replace the missing version, but the debt was never forgotten, nor the moral obligation to return an object. The music never sounded quite the same again to Amma and her relationship with her aunt, although still civil, never quite recovered from what had happened.

\section{Everyday habits in New York City}

In cases such as Amma's, where she believes she is in danger of becoming a witch, Akan priests describe witchcraft as so well hidden among everyday habits (and chores) that the exposure of evil becomes difficult and it will gradually contaminate the routines of a victim's life, even if the 'original' source of witchcraft is discovered hidden in a bracelet or another piece of jewellery. One priest compared this to leaving a cheap ring on a finger: eventually, he said, it will harm the hand. In this instance, Akan shrine spirits attempt to disrupt the relationship between the witch and her victim by changing the clients' habits and depositing what was once the associated ease and taken-for-grantedness of everyday life into a more turbulent, anonymous setting. First, a client is asked to bring in the item believed to be particularly contaminated with witchcraft. A health worker from Washington brought in a plate upon which she ate her favourite breakfast of waayke. Upon that plate, food tasted acidic to her, especially the boiled rice and beans that her aunt used to make her and which she missed when she first arrived in New York seven years ago. Another saw the colour red everywhere, a colour associated with the flesh and blood as the witch seeks to maim and kill her enemies (see Adinkrah, 2015). A woman brought her car key, another a small Afro-comb; a young African-American woman brought an earring, a Sierra Leonean administrator brought the necklace that she always wore, while a middle-aged woman from Atlanta brought a clump of her own hair. A further woman brought her favourite coffee which she felt the witch was making it taste bitter since she had mixed her evil into the blend. In isolating and 
then transferring those objects infected with obayi far away into a different setting, the shrine makes sure that these are not lost to occult forces which make personal objects seem increasingly foreign as the life of the victim is slowly stolen by the witch. Taking, therefore, particular objects from their everyday place, the priest plots the client's story, diverting it away from an inner, often claustrophobic world (see also Parish, 2011a). Particular objects are still in eventual reach of the client, but moved further afield, hidden in a big, fragmented, chaotic city, particularly Manhattan which many black African clients of West African religious practitioners do not know well at all.

Among Akan priests, in line with Akan ontology, it is argued that a superior knowledge allows particular spiritual agents to have sight of the immaterial world (Minkus, 1980; Yorder, 1982), and revolves around their in-depth surveillance of New York life where they can see 'behind happenings'. For priests, the successful observation of New York by their gods is made up of this most secret knowledge in their repertoire concerning especially the magic of Manhattan: its iconic past, etiquette, geography, skyscrapers, districts, inhabitants, trends, West African restaurants, and happenings. Threading the clients' lives throughout New York allows for the shrine to hide the 'normal' lives of individuals, but also has the function of allowing shrine gods, as they roam the urban landscape, to catch witches unawares as the latter gorge themselves on New York nightlife and mingle with the rich and famous (Parish, 2013).

One priest spoke of plunging his client's life metaphorically into the Hudson River. He spoke of watching the different tides and currents and how high tide at the Battery could be thirty minutes behind high tide uptown, throwing the witch into confusion. He told of following the current up to Long Island Sound. He kept pictures of the Atlantic Sturgeon, the fish most associated with the Hudson River, and a vial of river water. Another priest had no time for water but his knowledge always included New York's place in popular culture: cell phone photographs of the Empire State Building and Statue of Liberty, a concert programme from Madison Square Garden, a baseball ticket from the Yankee Stadium, a postcard of the ruins of the World Trade Centre, and a signed photograph of the past mayor of New York, Rudy Giuliani. Another kept baseball facts and statistics about the Mets printed out on reams of paper and a baseball cap under which he metaphorically 'hid' the client. Bruce, a priest in Brooklyn, collected cuttings from the New York magazine detailing families whom Mark 
Twain defined as opulent members of the 'gilded age' and who, in the nineteenth century, defined the American cultural and industrial landscape, among them the Carnegies, the Whitneys and the Vanderbilts. Added to this collection were the following pictorial representations: the interior of a Fifth-Avenue apartment; a picture of the New York philanthropist, Bunny Mellon; a map of the Hamptons, the exclusive Long Island resort where the rich take weekend breaks; a picture of a young John F. Kennedy and his daughter Caroline Kennedy, and so on (Parish, 2011b). Each collection constructed by Bruce tries to capture a bit of the Upper East Side. This can be a particular quality such as discreteness or social reserve - all embody the White, Anglo-Saxon, Protestant (WASP) quality that this shrine priest associates with New York and its urban dwellers (Parish 2011b).

Bruce also gathered newspaper clippings and virtual information about major incidents in New York behind whose violence and shootings he liked to disguise a client's routines. He then hid these symbolically in an elevator shaft in nearby buildings, wrapped in cloth. He also made lists of the trees on Fifth Avenue including three magnolia trees planted in Fifth Avenue Garden - two Saucer Magnolias and one Star Magnolia. He hid the 'easy times' of his clients' lives in amongst the smell of blossom and their branches. Another time, the same priest focused his particular interest on cabs driving throughout the city, his god eavesdropping on conversations and the journeys of passengers, 'leaving' his clients' 'home lives' concealed on the back passenger seat to continue the rest of their unknown journey uptown or downtown far away from the shrine client.

\section{The material purgatory of homeliness}

In Amma's life, the widening gap between her social imagination and what social life permitted became ignited by an agitation with her immediate surroundings. She felt things had gone “diabolical”. Amma went to an Akan priest despite never having suffered great gains or losses in her life. She had what she called an average life. "I not stand out in any way" she said. She thought that she smelt dull and had withdrawn from her surroundings. She felt closed in by odours, almost haunted by them (see also Parish 2011a). She felt that she could taste liquorice on her toothbrush - traditionally associated with a witch's presence. She recalled cooking her boyfriend's favourite food but being unable to taste the spices anymore. Instead, all she could sniff was gasoline. Her favourite soda no longer tasted the same - she wondered if the manufacturer had changed the ingredients. Her shoes pinched her feet. Her 
shampoo made her scalp itch. Every day was a bad-hair day. Her phone kept losing her contacts. Her clothes appeared creased and unkempt however much she washed them. Their colours faded. She no longer enjoyed watching TV and channel hopped all the time. Her friends seemed to have better things to do with their time than hang out with her. Following from Heidegger's (1996) notion of sein, the more she retreated, the more she became a ghost of herself. Her body seemed to be broken. Freud's description of the uncanny effects of the dismembered body are particularly pertinent as Amma describes how her head seemed too big for her neck and her feet now looked as if they belonged to another person. She had not looked at her stomach, she said, in years because "I fat and big" and felt that the lower half of her body had disappeared. She had read about a celebrity perfume and remembered the description of its scent as a calming, soothing baby's blanket, gentle and mellow. She wanted her life to smell like flowers and not dull and dreary. Her clothes, she now thought, looked silly and pretentious, the material cheap. She no longer recognised herself in photographs. She had loved listening to hiplife artists. When she listened to hiplife she thought about her family's migration to the United States and what they had left behind. She missed her home country. She read a lot of celebrity magazines about both West African and American actresses and rap stars while listening to music, but even this was not the same since the incident over the missing recording and made her sad and cut off from what was going on around her so that she "go nowhere... 'cause of all my bad thoughts turning ...turning... keeps me from my new start...”

Kwabena, at the lock-up, told her that he was going to immerse her in the world once more. First, she was asked to think of all the everyday things in her life and bring these to the shrine. These may be make-up, a manicure set, buttons or fabrics cut by her from blouses, skirts or trousers handed down by her mother, hair from a brush, bath oils poured into tiny vials, her iPod, phone texts, dirty bathwater or even bits of sauces or favourite food from unwashed cooking utensils that remind her of meal times, or threads from bed linen where her family slept. These were placed (or poured) onto a piece of clothing usually belonging to another client of Kwabena and, as the iPod played, rubbed daily with Britney Spears eau de parfum by the priest, when he was possessed by his god, to create new smelling sensations and new feelings. Amma complained how one "boyfriend... he got up and went... He not the one”. She dreamt of a new man in her life. “I’m casual 'bout these things... I do ... want 
babies $1 . .$. but not till I settle... my husband... he is gonna be generous and rich... and take care and buy gifts... and my life will be so filled .... with good”.

Freud (1983) tells us that the storyteller has a directive power to put us in different moods (Royle, 2012). Amma is asked to enjoy new experiences in the urban environment and explore new streets and recollect the first time she saw New York - its heat, its dirt, its smog, its noise. The first month she is asked to leave the Bronx and visit a part of Manhattan she does not know on the Upper West Side, or in Chelsea, and to wander around getting lost. She is asked to see herself for the first time doing this and think about her feelings and expectations when she turns a different street corner and to look at herself in a store window. She is told to exercise and enrol in a fitness programme. She is told to speak to people she does not know. She is instructed to read a newly published novel, to feel the spine and smell the paper, or visit a movie theatre she has never been before. She is specifically asked not to simply move her old routines to a new location but to try to discover 'new' loves that can combine with the most routine parts of her life in different settings.

Kwabena takes her private story and the notion of homeliness in order to go further afield and makes connections between items that do not lead back to Amma - not the opposite of closeness but a 'similar' material world created by the vision of the god. Each commonplace thing brought by Amma to Kwabena marks a turning point in her relationship with the witch: captured familiarity is misplaced within an iconic Manhattan - newspaper photographs and magazine cuttings of the Gramercy Hotel, West $13^{\text {th }}$ Street, Broadway, Alphabet City, Chelsea Hotel and Bellevue Hospital. One time, Kwabena, hid the chip from Amma's cell phone among flowers he had purchased from a high end store. On one occasion, Kwabena uploaded a picture of the street sign 'Avenue of the Americas' onto her computer. This, he said, gave the computer a new life and energy that could become real if Amma desired it. On another occasion, a favourite pair of shoes worn by Amma to church were wrapped in a map of Albany and the city hall together with a picture of the inside of a subway train. Kwabena then folds things belonging to Amma - her subway ticket to the shrine, strands of her hair, a used fork tied with pieces of sacred string or elastic bands washed in shrine 'medicine' pressed onto the sales card from the flower shop, or crumpled within a free newspaper from the day. Or her favourite bag of potato chips clipped to a fast-food wrapper. The paper bag was folded together with other bits and pieces Kwabena had collected from New York's streets and fast-food restaurants - a bar tab, a subway ticket, a beer mat etc - their corners cut 
and creased; their straight lines curled and folded (see Larkin 2008). Folding occurs several times over a period of one day. With each enfolding, Amma's everyday life is turned outward to reveal new shapes, contours and threads and blended into distinctive aspects of the city. By recycling the materiality of ordinary objects, Kwabena, when possessed, also acts as a storyteller by revealing his god's presence at various locations in the city and what the god sees from here. He repeats the chatter heard by the god over restaurant meals in Hell's Kitchen, couples whispering and drinking in bars in The Meatpacking District, cab drivers picking up fares, parties, tourists lost downtown, pickpockets, panhandlers, first dates in Brooklyn Heights, anniversaries and birthdays celebrated in apartments all over the city, weddings at the town hall, theatre crowds on Broadway and workers at Grand Central Station on their way home to Upstate New York - all of this is revealed to Amma from any one night viewing and her personal affects collapsed into the different material soundtracks of the city. New York plays an active role in manipulating personal objects to create a replicated world that becomes more powerful than the original and 'real' world. The witch's spirit is left behind in Amma's 'previous' life as the uncomfortableness she feels is weakened in a new familiar/strange realm. Her elusive everyday life - or, at least, the very parts she is losing - is gradually saved by the possibilities imagined by the appearance of something similar but also different as the shrine switches the most familiar parts of her world to a new setting, while discarding the worst bits that are too damaged to be retrieved. Amma's old possessions become rejuvenated and in her mind "fresh". When the client is still in danger of becoming the unintentional recipient of witchcraft, additional rituals are practised. Objects belonging to Amma that the priest has hidden may be later retrieved and spiritually cleansed by the offering of small sums of money to powerful suman or talismans thought to contain lesser or little abosom, charms which defy the distinction between spirit and matter. Thus by mobilizing the power of all manner of objects surrounding the victim, Kwabena will both defamiliarize and finally transform the personal into an uncanny space of anonymity.

\section{Conclusion: Replicating uncomfortableness}

In a chaotic disordered New York City, nothing seemed to ever happen to Amma. She had, in her opinion, suffered no great misfortune. She described her life as pretty normal and largely free of ill-health. But, she felt afraid and she could not pinpoint why. Her accustomed and ordered world appeared to be slowly disappearing before her very eyes and becoming odd. It is in the midst of the home that turmoil can be most terrifying and witchcraft a ticking time 
bomb and an expression of aggression among close kin (Geschiere, 2013b). For, while witchcraft discourses may be often viewed as an expression of social tension manifest in some sort of inexplicable event, its contamination from person to person is indicative of an alien presence in the ordinary lives of individuals, such that familiar surroundings and personal objects seemingly become uncomfortable and puzzling. The strangeness of the habitual is played out across Manhattan by shrine priests who realise that they need similarity to think about the unknown. Here, the relationship between the strange and the recurring is captured, as Geschiere (2013a) suggests, by Freud's (1919) concept of the uncanny and a sense of awkwardness. This is not simply a means of exorcising an evil spirit from an article such as a piece of jewellery or food as objects become opaquely twisted out of shape. Spiritual practices allow for alternative frames of hope to be created from the clients' own belongings. By focusing on how a "technology of the imagination” between people and things is realised, we can see how at shrines the realm of the material and the spiritual intersect (Sneath, Holbraad and Pedersen, 2009; Tassi, 2014). Akan occult discourses and witchcraft practices engage with 'intimate' aggression through ordinary objects that are distanced from the client and substituted within the chaos and feverishness of the city. In this movement, by transforming the strange and the known, the routine and the disorderly, the near and the far through the magical imagery of New York City, and especially Manhattan, witchcraft is stranded in Amma's old, accustomed life while her everyday routines remain largely preserved amongst transformed possibilities where she is no longer haunted by the stench of strangeness, evil and witchcraft.

\section{Notes}

All names have been changed in order to preserve the anonymity of participants.

\section{References}

Adinkrah, M (2015) Witchcraft, Witches and Violence in Ghana. London: Berghahn

Appadurai, A (1996) Modernity at Large. Cultural Dimensions of Globalization. London: University of Minnesota Press

Benjamin, W (1996) On the Mimetic Faculty., In: Jennings, M.W. Eiland,H and Smith, G (eds) Selected Writings, 1926-1934. Cambridge, MA: Belknap Press. 
Bonhomme, J (2012) The dangers of anonymity: Witchcraft, rumour, and modernity. Hau journal Vol 2, No 2:205-233

Chapman, T and Hockey, S (1999) Ideal Homes: Social Change and Domestic Life. London: Routledge

Crapanzano, V ( 2004) Imaginative Horizons. An Essay on Literary Philosophical Anthropology. Chicago: University of Chicago

Crentsil, P ( 2005) A dark world. Supernaturalism and illness among the Akan of Ghana Suomen Anthropologi Vol 30, 1:53-72

Da Col, G (2012) The Poisoner and the Parasite: Cosmoeconomics, fear and hospitality among Dechen Tibetans. Journal of the Royal Anthropological Institute Vol 18:175-195

Debrunner, H (1959) Witchcraft in Ghana. Ghana: Presbyterian Book Depot

Douglas, M (1970) Witchcraft Confession and Accusation. London:Routledge

Druker-Brown, S (1975) Ritual aspects of the Mamprusi kingship. Cambridge: Cambridge University Press

Englund, H and Leach, J (2000) Ethnography and the meta narratives of modernity. Current Anthropology Vol 41(2):225-248

Englund, H (2007) Witchcraft and the limits of mass-mediation in Malawi. JRAI 13(2):295311

Field, M J (1960) Search for security. London: Faber \& Faber.

Freud, S (1983) (1919) The Uncanny. Pelican Freud Library 14. Hamondsworth: Penguin

Geschiere, P (1997) The Modernity of Witchcraft Politics and the Occult in Postcolonial Africa. Virginia: The University of Virginia Press 
Geschiere, P (2013a) Witchcraft, Intimacy and Trust. Africa in Comparison. Chicago: University of Chicago Press

Geschiere, P (2013b) Sociality and Its Dangers. Witchcraft, Intimacy and Trust in Nicolas J. Long and Henrietta Moore (eds). Sociality: New Directions. Oxford: Berghahn Books Giddens, A (1992) The Transformation of Intimacy. Oxford: Blackwell Goody, J (1957) Anomie in Ashanti. Africa 27: 356-63.

Goody, E (1970) Legitimate and Illegitimate Aggression in a West African State. In: Douglas, M. Witchcraft Confession and Accusation. London: Routledge, pp207- 229

Handleman, D (2008) Afterward. Returning to Cosmology. Thoughts on the Positioning of Belief. Social Analysis Vol 52, 1:181-195.

Harvey, P and Knox. H (2014) Introduction: Objects and Materials. In: Harvey, P, Conlin Casella, E, Evans, E (eds) Objects and Materials. A Routledge Companion. London: Routledge:1-19

Heidegger, M (1996) Holderlin’s Hymn The Ister. Bloomington: Indiana University Press Henare, A, Holbraad, M, Wastell, Sgi (2006). Thinking Through Things: Theorising Artefacts Ethnographically. London: Routledge: 1-23

Institute for Children, Poverty and Homelessness. 2014. A Bronx Tale. The Doorway to Homelessness in New York City. New York: ICPN

Ishii, M (2012) Acting with things. Self-poiesis, actuality, and contingency in the formation of divine worlds. HAU: Journal of Ethnographic Theory 2 (2), 371-388

Kraus, K and Huewelmeier, G (2010) Travelling Spirit. Migrants, Markets and Mobilities. London: Routledge

Larkin, B (2008) Signal and Noise: Media, Infrastructure and Urban Culture in Nigeria. Virginia: Duke University Press.

Lupton, D (2013) Risk. London: Routledge 
Masschelen, A (2011). The Unconcept. The Freudian uncanny in late twentieth century theory. New York: SUNY

McLeod, M (1981) The Asante. London: British Museum Publication

Meyer, B (1998) The Power of Money: Politics, Occult Force, and Pentecostalism in Ghana. African Studies Review 41(3): 15-37.

Minkus, H (1980) The Concept of Spirit in Akwapim Akan Philosophy. Africa 50, no. 2: 182-92.

Moore, H and Todd Sanders (2001) Introduction. In: Moore, H and Todd Sanders (eds) Magical Realities. Magical Interpretations. London: Routledge.

Palmer, K (2013) Spellbound. Inside West Africa's Witch Camps. England: Free Press

Parish, J (2011a) Social Suffering and anxiety: deciphering coughs and colds at Akan antiwitchcraft shrines in Paris, Anthropology and Medicine Vol 18, 3:303-315.

Parish, J (2011b) West African witchcraft, wealth and moral decay in New York City. Ethnography 4(3), 136-151.

Parish, J (2013) Chasing Celebrity: Akan witchcraft in New York. Ethnos 3:4: 85-102 Parish, J (2015) Beyond occult economies: Akan Spirits, New York Idols and Detroit Automobiles, HAU Journal of Ethnographic Theory Vol 5(2): 101-120

Rattray, R. S (1927). Religion and Art in Ashanti. Oxford: Oxford University Press Royle, N (2003) The Uncanny. Manchester: Manchester University Press.

Simpson, N (2013) Unravelling the mystery of witchcraft. Accra, Ghana: Combert Impressions

Simmel, G (1950) The Sociology of Georg Simmel. New York: Free Press

Strathern, A and Stewart, P.A (2004) Witchcraft, sorcery, rumours and gossip. Cambridge: Cambridge University Press. 
Tassi, N and Santo, D.S (2014) Making Spirits: Materiality and Transcendence in Contemporary Religions. London: IB Tauris

Taussig, M (1993) Memesis and Alterity. London: Routledge

Trovalla, U and Andersson (2011) Medicine for Uncertain Futures. A Nigerian city in the wake of crisis. Uppsala: Uppsala University

Vidle, A. (1992) The Architectural Uncanny. Essays in the Modern Unhomely. Cambridge: MIT Press.

Yoder, P.S (1982). Introduction. In: Yoder, P.S (ed). African health and healing systems:

Proceedings of a symposium. Los Angeles: Crossroads Press

Zizek, S (2013) Event. Philosophy in Transit. London: Penguin Books 